\title{
Kadmiumstressz detektálására alkalmazható in situ és destruktív mérési módszerek összehasonlító vizsgálata búzán
}

\author{
$1 *$ KelEMEN Bettina, ${ }^{1}$ FÜZY Anna, ${ }^{1}$ CSERESNYÉS Imre, ${ }^{1,2}$ PARÁDI István, ${ }^{1}$ KovÁCs \\ Ramóna, ${ }^{1}$ RAJKAI Kálmán, ${ }^{1}$ TAKÁCS Tünde \\ ${ }^{1}$ Agrártudományi Kutatóközpont, Talajtani és Agrokémiai Intézet, Budapest \\ ${ }^{2}$ ELTE TTK Növényélettani és Molekuláris Növénybiológiai Tanszék, Budapest
}

\section{Bevezetés}

A kadmium (Cd) a növényi stresszélettani kutatások során gyakorta alkalmazott környezeti stressztényező. Toxicitása és vízoldhatósága egyaránt jelentős, a talajok és a vizek Cd-szennyezése mind környezeti, mind pedig humán egészségügyi szempontból nagy kockázatot jelent (HUANG et al., 2008). Optimális esetben a szennyezetlen talajokban a $\mathrm{Cd}$ mennyisége az alapkőzet tulajdonságaitól függ. Főként légköri ülepedésből, mütrágyákból, komposztokból és egyéb helyi emissziós forrásokból kerülhet a talajba (KHAN et al., 2017; SzABÓ et al., 2019). Hazai viszonylatban a talajok kadmium-szennyezésének legföbb forrása a mütrágyahasználat. A magyarországi talajok átlagos Cd-tartalma alacsonynak mondható, koncentrációja a felső $30 \mathrm{~cm}$-es rétegben általában $0,5-1 \mathrm{mg} \mathrm{kg}^{-1} \mathrm{között}$ változik (CSATHÓ, 1994; SIMON, 2014). Problémát jelenthet, hogy a mezőgazdasági művelés alatt álló talajaink nagy része erősen savas vagy savas kémhatású, ami növeli a Cd oldhatóságát, ezáltal a növények Cd-felvétele és felhalmozása is jelentősebb. Ebből adódóan a savanyú talajokon lényegesen nagyobb a kockázata annak, hogy a Cd a táplálékláncba kerülve az ember egészségét is veszélyezteti. Bár a növények a Cd-ot látható tünetek nélkül is képesek felhalmozni, általában már kis koncentrációban is markáns fejlődési és élettani változásokat vált ki. Hatása leginkább a vas-anyagcsere megzavarásában, a klorofill bioszintézisének a gátlásában, valamint a fotoszintetikus apparátus felépítésének és múködésének gátlásában nyilvánul meg (PARMAR et al., 2013). A növények többsége a Cd-ot a gyökerében halmozza fel (LUX et al., 2011). A növényfajok Cd türöképességében, kizárásában vagy felhalmozásának mértékében jelentősek a különbségek. Számos szerző számolt be a kadmiumot felhalmozó növénycsaládok, pl. a keresztesvirágúak (Brassicaceae) fitoremediációs felhasználási lehetőségeiről (ANJUM et al., 2014).

A növények stressztoleranciáját a velük szimbiózisban élő növényi növekedés serkentő talajbaktériumok (plant growth promoting rhizobacteria) és mikorrhiza gombák is elősegíthetik (JHA \& SARAF, 2015; PARNIKSE et al., 2008). A szárazföldi ökoszisztémákban legelterjedtebb mikorrhiza típus az arbuszkuláris mikorrhiza (AM). Az AM gombák (Glomeromycota törzs) obligát aerob mikroorganizmusok, amelyek a szárazföldi növények 80-90 \%-ával - köztük a legtöbb gazdaságilag fontos haszonnövényünkkel - élnek kölcsönösen elönyös szimbiózisban (BRUNDRETT \& TEDERSOO, 2018). Az AM gombák gyökérbeli kolonizációja bizonyítottan növeli a gazdanövények tápanyag- és vízfelvételét, befolyásolja

*Levelezö szerzö: KelEMEN BetTinA, Agrártudományi Kutatóközpont, Talajtani és Agrokémiai Intézet, 1022 Budapest, Herman Ottó út 15.

E-mail:kelemen.bettina@atk.hu 
továbbá a növények hormonháztartását. Következésképp az AM kedvezően hat még szennyezett talajokban is a növények fitneszére és vitalitására (PARNISKE, 2008; SMITH \& SMITH, 2012). A talajok fémszennyezése azonban akár teljesen megakadályozhatja a növény-gomba közti szimbiózis kialakulását, a gombák spóraképzését, a spórák csírázását és a hifák növekedését. Ugyanakkor számos szerző kimutatta, hogy az AM gombák a tartós Cd-szennyezéshez toleráns ökotípusok kialakulásával képesek alkalmazkodni (TAKÁCS, 2012). Az AM gombák fémtoleranciájának mechanizmusa összetett, és nem teljesen tisztázott. A nehézfémek sejtfalakban és vakuólumokban történő lekötése (immobilizációja) lehet az AM gombák alapvető méregtelenítő mechanizmusa (FERROL et al., 2009). A glomalin egy az AM gombák hifái által kiválasztott glikoprotein, amely javítja a talajszemcsék aggregációját és vízmegtartó képességét, továbbá köti a fémeket is (KRISHNAMOORTHY et al., 2019).

A növények ellenálló képességének, a sokféle és változó környezeti feltételekhez való alkalmazkodás mechanizmusainak felderítése az agrár- és ökológiai kutatásokban is kulcsfontosságú. A stresszhatásokra adott növényi válaszreakciók detektálása során elengedhetetlen a növekedésben és az anyagcserében bekövetkező változások minél szélesebb körü vizsgálata. A sikeres vizsgálat előfeltétele a megfelelően érzékeny indikátorok és a mérendő paraméterek helyes megválasztása, ami azonban nem feltétlenül nyilvánvaló. Figyelembe kell venni, hogy egyes indikátorok hatékonysága növényfajonként és azok különbözö fenofázisaiban is más.

A klasszikus növényélettani vizsgálati módszerek, például a levelek klorofilltartalmának és fotoszintetikus aktivitásának meghatározása, a különböző növényi részek makro- és mikroelem-tartalmának mérése, az antioxidatív enzimaktivitás, az anyagcseretermékek és a szerves savak koncentrációinak mérése mind jó eszköze a stresszélettani kutatásoknak (SHANYING et al., 2017). Egyszerűen mérhető paraméter a gyökér és a hajtás biomasszája, a gyökér- és a hajtásbiomassza aránya, a termés mennyisége és a levelek felülete. A gyökér-talaj együttes elektromos kapacitásának mérése roncsolásmentes módszer a gyökérnövekedés és aktivitás változások észlelésére (CSERESNYÉs et al., 2013). A növényfejlödés nyomon követése egyszerűen megfigyelhető bonitálással, mérhető és számolható paraméterekkel pl. növénymagasság, szárcsomók, levelek, virágok száma, szárátmérő, toxicitás szemmel látható tünetei stb., továbbá modern optikai fenotipizáló módszerekkel lehetséges (LI et al., 2014). A növényi stresszválaszreakciókat a különböző növényi szervek vízállapota és a növény transzspirációja is jól jellemzi (VERSLUES, 2006). A sejtmembrán stabilitási mutatók értékes információkat szolgáltatnak a növényi sejtek állapotáról. A növényi anyagcsere és a szabályozó mechanizmusok dinamikájának tanulmányozását a hagyományos élettani vizsgálatok mellett hasznosan kiegészíti a transzkriptomikus, proteomikus és metabolomikus elemzés (CHAVES et al., 2009). A növénnyel együtt élő (szimbionta) mikroorganizmusok kolonizáló képességének alakulása a stresszor jelenlétében a szimbiotikus kapcsolat müködőképességére utal (FÜZY et al., 2007).

Vizsgálatainkban tenyészedény-kísérletet állítottunk be különböző dózisú kadmiumkezelések hatásának vizsgálatára tavaszi búza [Triticum aestivum L. cv. 
TC-33] növekedési és élettani paramétereire arbuszkuláris mikorrhiza gombával oltott és nem oltott növényeken. In situ és destruktív vizsgálati módszereket hasonlítottunk össze arra vonatkozóan, hogy az ily módon gyüjtött adatok milyen mértékben jelzik a Cd-stressz erősségét, és az AM gombával történő oltás hatását. Módszertani szempontból vizsgáltuk a talaj-növény együttesben az elektromos kapacitásmérés alkalmasságát, a Cd hatására a gyökérrendszer aktivitásában bekövetkező változások révén.

\section{Anyag és módszer}

A tesztnövények nevelési körülményei

A tenyészedényeket $\left(0,85 \mathrm{dm}^{3}\right) 500 \mathrm{~g}$ riolit és vermikulit 1:1 (v:v) arányú keverékével ( $\mathrm{pH}_{\mathrm{H} 2 \mathrm{O}}$ : 7,47; térfogattömeg: $0,67 \mathrm{~kg} \mathrm{dm}^{-3}$, CEC: $9,13 \mathrm{mmol} 100 \mathrm{~g}^{-1}$; szabadföldi vízkapacitás $0,39 \mathrm{~cm}^{3} \mathrm{~cm}^{-3}$ ) töltöttük meg.

Kísérleti növényként tavaszi búzafajtát [Triticum aestivum L. cv. TC-33] használtunk. Kadmiumkezelésként [kontroll, $\mathrm{Cd} 1, \mathrm{Cd} 2, \mathrm{Cd} 3$ ], a növénynevelö közeg egyszeri öntözésére $3 \mathrm{CdSO}_{4} * 8 \mathrm{H}_{2} \mathrm{O}$ oldatot alkalmaztunk. A kísérletet a kadmiumterhelés négy dózisával ( $0 ; 1 ; 2,5$ és $5 \mathrm{mg} \mathrm{kg}^{-1}$ nevelöközeg) kezelésenként 15 ismétlésben állítottuk be.

A magokat steril Petri-csészében, desztillált vízzel átnedvesített szürőpapíron $28^{\circ} \mathrm{C}$-os termosztátban csíráztattuk. Az edényekbe $1 \mathrm{~cm}$ mélységben 1-1 kicsírázott magot ültettük. A tenyészedények elhelyezése a klímakamrában véletlenszerü volt, hetente változtatott pozícióval. A klímakamrás növénynevelés 42 napig 16 órás fényszakasz $\left(26-27{ }^{\circ} \mathrm{C} ; \sim 600 \mu \mathrm{mol} \mathrm{m}{ }^{-2} \mathrm{~s}^{-1} \mathrm{PAR}\right)$, valamint 8 órás sötétszakasz $\left(17-18^{\circ} \mathrm{C}\right)$ mellett történt. A relatív páratartalom $60-70 \%$ között változott.

Az AM gombák növényekre gyakorolt hatásának vizsgálatára mikorrhiza gombával oltott és nem oltott növénycsoportokat használtunk. Az AM gombával oltást Rhizoglomus intraradices (sin. Glomus intraradices) riolit (Colas Co. Ltd., Tarcal, Hungary) és vermikulit (Pull Rhenen B. V., Rhenen, The Netherlands) 1:1 (v:v) arányú keverékében elöállított, kolonizált gyökerek és a közeg homogén keverékével, mint oltóanyaggal végeztük $[\operatorname{kontroll}(+), \operatorname{Cd} 1(+), \operatorname{Cd} 2(+), \operatorname{Cd} 3(+)]$ $10 \mathrm{~g} /$ tenyészedény mennyiségben.

A növényeket mérlegen mérve és azonos tömeg eléréséig naponta öntöztük csapvízzel, és hetente egy alkalommal $50 \mathrm{~cm}^{3}$ csökkentett foszfortartalmú $(0,1 \mathrm{mM}$ $\mathrm{KH}_{2} \mathrm{PO}_{4}$ ) Hoagland-oldattal locsoltuk.

\section{A fotoszintetikus aktivitás mérése és klorofilltartalom meghatározása (CCI)}

A növények fotoszintetikus aktivitását klorofill fluoreszcencia mérésén keresztül, az Fv/Fm paraméter meghatározásával jellemeztük. A mérés OS30 ${ }^{+}$ klorofill fluoriméterrel (Opti-Sciences, Hudson, USA), 10 perces sötétadaptációt követően történt. A kvantumhasznosítást és a levelek klorofilltartalmát minden esetben a növény legfiatalabb, kifejlett levelén határoztuk meg. A növény leveleinek roncsolásmentes klorofilltartalom mérését CCM-200 plus Chlorophyll Meter (ADC BioScientific Ltd.) készülékkel végeztük. A közölt CCI értékek minden esetben 
azonos levélen, azonos időben mért 3 érték átlagai. A CCI (CCI1 és CC2) és Fv/Fm $(\mathrm{Fv} / \mathrm{Fm} 1$ és $\mathrm{Fv} / \mathrm{Fm} 2)$ méréseket 22 és 36 napos növényeken végeztük.

\section{Elektromos kapacitás mérése}

A gyökérkapacitást $\left(C_{R}\right)$ és a hozzátartozó szóródási vagy disszipációs faktort (D) GW-8101G LCR-müszerrel (GW Instek Co. Ltd., Taiwan) mértük $1 \mathrm{kHz}$ frekvencián, $1 \mathrm{~V}$ feszültséggel, párhuzamos eredő kapacitásként. Talajelektródként $6 \mathrm{~mm}$ átméröjü, $15 \mathrm{~cm}$ hosszú acélrudat, növényelektródként a szárra $10 \mathrm{~mm}$ magasságban elhelyezett csipeszt alkalmaztunk. A csipeszt $5 \mathrm{~mm}$ széles alufólián keresztül rögzítettük, mely alatt a szárat áramvezető géllel kentük körbe. A mérést mindig a nevelöközeg szabadföldi vízkapacitásra öntözése után végeztük. A talajnedvességet $0-11 \mathrm{~cm}$ rétegben Trime-HD2 típusú TDR müszerrel (IMKO GmbH., Ettlingen, Germany) Pico32 elektróddal mértük. A $C_{R}$ mérések a növények $26\left(C_{R} 1\right)$ és $42\left(C_{R} 2\right)$ napos korában történtek.

\section{Biomassza és levélfelület mérése}

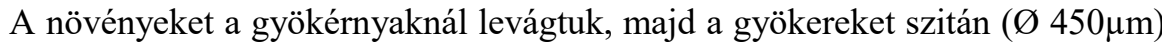
átfolyó víz alatt kimostuk. A mosott gyökereket papírtörlővel leitattuk, majd tömegüket analitikai mérlegen megmértük. A gyökerekböl MSI vizsgálatra $0,1 \mathrm{~g}$ és gyökérkolonizáció meghatározására $0,3 \mathrm{~g}$ tömegủ mintát vettünk, ezt követően a gyökérzet fennmaradó részét megszárítottuk. A gyökerek és a hajtás száraztömegét tömegállandóságig szárítva $\left(70^{\circ} \mathrm{C}, 72 \mathrm{~h}\right)$ határoztuk meg. A leveleket eltávolítva a levágott hajtásról, a levélfelületet (LA) szkenneléssel mértük (LI-3100C, LI-COR Biosciences GmbH, Bad Homburg, Germany).

\section{Membránstabilitási index}

A membránstabilitási indexet (MSI) közvetlenül a kísérlet bontását követően vezetőképesség mérésével határoztuk meg (SAIRAM et al., 1997). A több ponton megmintázott gyökérrendszert desztillált vízbe helyeztük és hőkezelés után MultiLine P4 univerzális mérömüszerrel (TetraCon 325 standard vezetőképesség cellával) mértük a vezetőképességét szobahőmérsékletre visszahűtés után. A mérések eredményét a gyökerek nedves tömegére vonatkozóan a következő számítási mód alapján adtuk meg: MSI=[1-(c1/c2)*100], ahol c1 a $40{ }^{\circ} \mathrm{C}$-os hökezelés utáni, c2 pedig a $90^{\circ} \mathrm{C}$-os hőkezelés utáni oldatok vezetőképessége $\left(\mu \mathrm{S} \mathrm{cm}^{-1}\right)$.

\section{Gyökérkolonizáció vizsgálata}

Az AM gombák gyökérkolonizációjának vizsgálatára a gyökerek anilinkékkel történő festését (PHILLIPS \& HAYMAN, 1970) követően Olympus BX51 (Olympus Corp., Tokyo, Japan) fénymikroszkópot használtunk (40-200-szoros nagyítás). A gyökérkolonizációs mutatókat (mikorrhizáltság intenzitása $=\mathrm{M} \%$, abszolút arbuszkuláltság $=\mathrm{A} \%$ ) TROUVELOT és munkatársai (1986) módszere szerint határoztuk meg. 
Növények kadmium- és foszforkoncentrációjának meghatározása

A különböző növényi szervekben a nevelő közegből felvett Cd és P kimutatása cc. $\mathrm{HNO}_{3}+$ cc. $\mathrm{H}_{2} \mathrm{O}_{2}$ feltárás után ICP-AES (Jobin-Yvon, ULTIMA2) mérés alapján, a Magyar Szabvány útmutatása szerint történt (MSZ 21470-50:2006).

\section{Statisztikai analízis}

Az adatok elemzését az R-statistic programcsomaggal végeztük ( $\mathrm{R}$ Core Team, 2019). Az adatmátrix elemzéséhez fökomponens-analízist (Principal Component Analysis $=$ PCA) használtunk, az adatpontokat és vektorokat a két legnagyobb sajátértékü komponens függvényében ábrázoltuk. A mért paramétereket kéttényezős varianciaanalízissel elemeztük. A statisztikai elemzés előtt az AMF adatoknál négyzetgyök transzformációt végeztünk. A szórás-homogenitás ellenőrzésére Bartlett-tesztet használtunk, míg az adatok eloszlását SHAPIRO-WILK normalitás teszttel ellenőriztük. Amikor az ANOVA feltételek nem teljesültek, az adatokon ART (Aligned Rank Transformation) transzformációt végeztünk (WOBBROcK et al., 2011). Az átlagértékeket TUKEY-féle post-hoc teszttel hasonlítottuk össze $95 \%$-os konfidencia-intervallumokon. A nem parametrikus tesztekre NEMENYI-tesztet alkalmaztunk.

\section{Eredmények}

A főkomponens analízissel a fö hatótényezők változóinak kapcsolatát és szétválásuk hatékonyságát vizsgáltuk ( $1 A$. ábra). A PC1-nél a Cd hatása egyértelmü, a kontroll- és Cd-kezelések minimális átfedéssel, de jól láthatóan szétválnak. A PC2-ben az AM gomba oltás hatása felismerhetóen szétválik. A Cd-terhelésre jó indikátor lehet a hajtás-, a gyökér biomassza, a levélfelület és a $\mathrm{C}_{\mathrm{R}}(1 \mathrm{~B}$. ábra $) . \mathrm{Az}$ MSI és a D szerepe elhanyagolható mind az 1-es és a 2-es fökomponens mentén (1B. ábra).

Növényi stresszválasz az in situ és a destruktív vizsgálatok alapján

A PSII reakciócentrumok maximális kvantumhatékonysága $(\mathrm{Fv} / \mathrm{Fm})$ a kontrollhoz viszonyítva szignifikánsan csökkent a legnagyobb Cd-terhelés hatására (1. táblázat). Az AM gomba oltás hatása nem volt kimutatható.

A CCI értékben kifejezett klorofilltartalom a búza leveleiben minden kezelés esetén kisebb volt a kontrollhoz viszonyítva. Szignifikáns klorofilltartalom csökkenést figyeltünk meg a $\mathrm{Cd} 2$ és a $\mathrm{Cd} 3$ kezelésủ növények esetében, ahol a Cd2-kezelt növény esetén 29,9 \%-os, a Cd3 növény esetén pedig 35,9 \%-os csökkenését tapasztaltuk (1. táblázat). A CCI értékekben az AM gomba oltás számottevő változást nem okozott. 

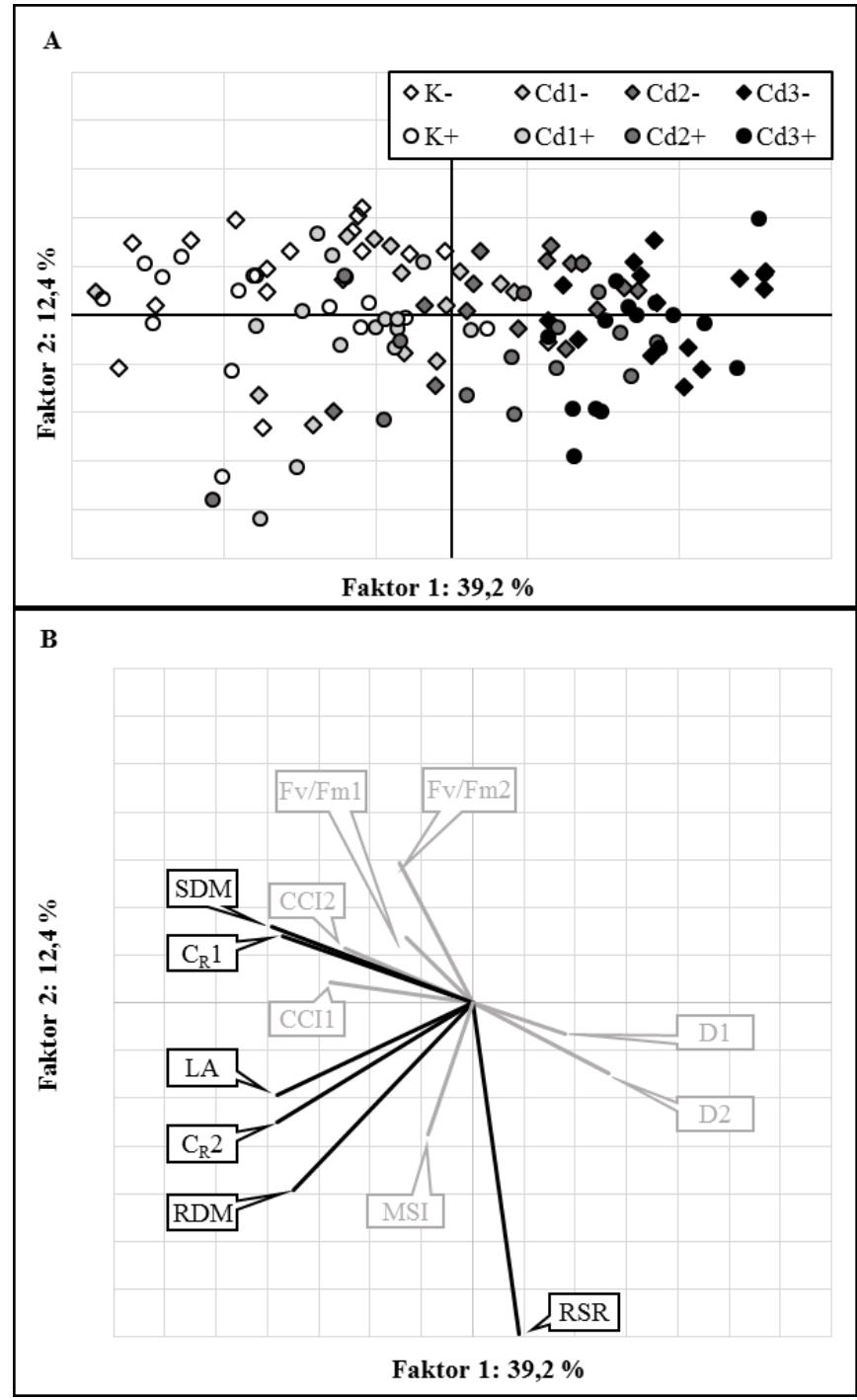

1. ábra

A főkomponens-analízis eredménye. (A) a minták eloszlása a koordináta-rendszerben és (B) a paraméterek szétválása.

Jelölések: fotoszintetikus aktivitás (Fv/Fm); klorofilltartalom (CCI); (Fv/Fm1 és CCI1- 22 napos növény, az Fv/Fm2 és CCI2- 36 napos növény), gyökerek elektromos kapacitása $\left(\mathrm{C}_{\mathrm{R}}\right)$; $C_{R} 1$ - 26 napos növény és $C_{R} 242$ napos növény, szóródási faktor (D); D1 - 26 napos növény

és D2- 42 napos növény, membrán stabilitási index (MSI), gyökér száraztömeg (RDM), hajtás száraztömeg (SDM), gyökér/hajtás arány (RSR), levélfelület (LA).

A Cd-terhelés hatására a $C_{R}$ csökkent (1. táblázat). A $C_{R}$ értékekben szignifikáns különbséget találtunk a kadmiumkezelések között. Az AM gombával oltott (AMF+) 
növények kapacitás értéke minden esetben nagyobb volt $(9,6-18,4 \%)$, mint az oltatlanoké (AMF-). A nem mikorrhizált növényeken a Cd-mal nem kezelt (kontroll) növényekhez viszonyítva szignifikáns csökkenés tapasztalható a közepes Cd-terhelési dózison (Cd2), amelynek mértéke 26,8\%. A legnagyobb Cd-dózisnál (Cd3) a csökkenés elérte a 43,4 \%-ot. Az AM gombával oltott növényeken a kisebb Cd-dózis a $\mathrm{C}_{\mathrm{R}}$ értékekben enyhébb csökkenést okozott. $\mathrm{A} \mathrm{Cd} 2$ terhelést kapott növényeken $21 \%$, míg a Cd3 dózisban $45,1 \%$ volt a $C_{R}$ csökkenése. Az AM gombával oltás a Cd2 növényeken 18,5 \%-kal növelte a gyökérkapacitást, míg a Cd3 növényeken a növekedés $12,8 \%$ volt.

Az MSI értékekben a növekvő Cd dózisok hatására kismértékủ csökkenés volt kimutatható: Cd1-terhelt növényeknél 3,8\%-kal, a Cd2 növényeknél 5,3\%-kal, a Cd3 növényeknél pedig 6,8\%-kal csökkent az MSI. Azonban az MSI értékek között sem a Cd-kezelések, sem az AM gomba oltás hatására szignifikáns különbség nem volt kimutatható.

A Cd koncentrációja a hajtásban a Cd-terhelés növekedésével szignifikánsan nőtt. A kontrollhoz viszonyítva a kadmium koncentrációja 19-43-szeresére nőtt a búza hajtásában (1. táblázat). A Cd3-terhelés esetében, mind az AM gombával kezelt, mind a nem mikorrhizált növények hajtásának foszfortartalma $20 \%$-kal nőtt. A hajtás Cd- és P-tartalmára az AM gomba oltás hatása nem volt kimutatható.

A Cd-terhelés hatására a gyökerek Cd- és P-koncentrációja a hajtáshoz hasonlóan alakult, viszont a mikorrhiza jelenléte szignifikánsan növelte a Cd- (AMF+: 79,7 mg kg-1; AMF-: 63,3 mg kg-1) és P- (AMF+: $854 \mathrm{mg} \mathrm{kg}^{-1}$; AMF-: $742 \mathrm{mg} \mathrm{kg}^{-1}$ ) tartalmat (1. táblázat). A TC33 búzafajta a gyökerében halmozta fel a kadmiumot, ezért a gyökerekben a hajtáséhoz képest a kadmium 4,5 és 5,5szeres koncentrációban volt jelen (adatot nem közlünk).

Növekedési paraméterek: növényi biomassza, gyökér/hajtás arány, levélfelület

A kontroll növényekhez viszonyítva (AMF-, $\mathrm{Cd} 0)$ az oltatlan a Cd3 növények gyökértömege jelentös, 36,7 \%-os csökkenést mutatott (2. táblázat). Az AM gombával oltott $\mathrm{Cd} 3$ növények gyökerének biomasszája a kontrollhoz képest (AMF+; Cd0) 32,5\%-kal kisebb volt. Az AM gombaoltás a kontroll növényeken 7,4 \%-os, a Cd1-kezelésben 9,7\%-os, a Cd2-kezelésben 17,6\%-os és a Cd3-kezelésben 14,5\%-os tömegnövekedést eredményezett. A gyökértömeg az AM gombával oltott $(\mathrm{AMF}+)$ növényekben szignifikánsan nagyobb volt, mint a nem mikorrhizáltaké (AMF-). Az AM gombaoltás átlagosan 11,8 \%-kal növelte a növények gyökértömegét.

A hajtások biomasszáját a kontroll növényekhez képest a $\mathrm{Cd}$ jelenléte jelentősen csökkentette. A Cd1 dózissal kezelt növényeknél 23,8 \%-os csökkenést, a Cd2 dózis esetén 36,6 \%-os csökkenést, a Cd3 dózisnál pedig 51,8 \%-os csökkenést tapasztaltunk a hajtásbiomasszában (2. táblázat). Az AM gombaoltás hatására ebben számottevő változás nem volt megfigyelhető. 


\section{1. táblázat}

Növényi stresszválasz és elemfelvétel kadmium terhelés (kontroll: $0 ; \mathrm{Cd} 1: 1 ; \mathrm{Cd} 2: 2,5$ és $\mathrm{Cd} 3$ : 5 mg Cd kg${ }^{-1}$ nevelöközeg; $\mathrm{n}=15$ ) hatására, mikorrhizált ( $\mathrm{AMF}+$ ) és nem mikorrhizált $(\mathrm{AMF}-)$ növények esetén

(1)

\begin{tabular}{|c|c|c|c|c|c|c|}
\hline Paraméterek/Kezelések & & (IF- & & IF + & & \\
\hline (2) Fv/Fm2 & (3) átlag & (4) szórás & átlag & szórás & átlag & (5) szign \\
\hline Kontroll & 0,809 & $\pm 0,008$ & 0,811 & $\pm 0,007$ & 0,810 & $\mathrm{a}$ \\
\hline $\mathrm{Cd} 1$ & 0,809 & $\pm 0,010$ & 0,812 & $\pm 0,009$ & 0,811 & $\mathrm{a}$ \\
\hline $\mathrm{Cd} 2$ & 0,809 & $\pm 0,011$ & 0,806 & $\pm 0,011$ & 0,808 & $a b$ \\
\hline $\mathrm{Cd} 3$ & 0,805 & $\pm 0,012$ & 0,801 & $\pm 0,014$ & 0,803 & $\mathrm{~b}$ \\
\hline átlag/szign. & 0,808 & A & 0,808 & A & & \\
\hline (6) CCI2 & átlag & szórás & átlag & szórás & átlag & szign. \\
\hline Kontroll & 9,360 & $\pm 2,440$ & 8,140 & $\pm 2,573$ & 8,750 & $\mathrm{a}$ \\
\hline $\mathrm{Cd} 1$ & 7,280 & $\pm 1,883$ & 7,787 & $\pm 1,858$ & 7,534 & $a b$ \\
\hline $\mathrm{Cd} 2$ & 6,527 & $\pm 2,221$ & 5,747 & $\pm 1,991$ & 6,137 & $\mathrm{bc}$ \\
\hline $\mathrm{Cd} 3$ & 5,013 & $\pm 1,867$ & 6,207 & $\pm 2,252$ & 5,610 & $\mathrm{c}$ \\
\hline átlag/szign. & 7,045 & A & 6,970 & A & & \\
\hline (7) $C_{R} 2(n F)$ & átlag & szórás & átlag & szórás & átlag & szign. \\
\hline Kontroll & 4,313 & $\pm 0,943$ & 4,732 & $\pm 0,970$ & 4,523 & $\mathrm{a}$ \\
\hline $\mathrm{Cd} 1$ & 4,002 & $\pm 1,041$ & 4,442 & $\pm 0,708$ & 4,222 & $\mathrm{a}$ \\
\hline $\mathrm{Cd} 2$ & 3,156 & $\pm 0,833$ & 3,736 & $\pm 0,814$ & 3,446 & $\mathrm{~b}$ \\
\hline $\mathrm{Cd} 3$ & 2,440 & $\pm 0,478$ & 2,751 & $\pm 0,555$ & 2,596 & $\mathrm{c}$ \\
\hline átlag/szign. & 3,478 & A & 3,915 & B & & \\
\hline (8) MSI & átlag & szórás & átlag & szórás & átlag & szign. \\
\hline Kontroll & 37,282 & $\pm 5,086$ & 44,540 & $\pm 7,195$ & 40,911 & $\mathrm{a}$ \\
\hline Cd1 & 40,383 & $\pm 3,590$ & 38,356 & $\pm 5,968$ & 39,370 & $\mathrm{a}$ \\
\hline $\mathrm{Cd} 2$ & 40,502 & $\pm 4,101$ & 37,005 & $\pm 5,811$ & 38,754 & $\mathrm{a}$ \\
\hline $\mathrm{Cd} 3$ & 39,062 & $\pm 3,899$ & 37,177 & $\pm 4,730$ & 38,120 & $\mathrm{a}$ \\
\hline átlag/szign. & 39,307 & A & 39,270 & A & & \\
\hline (9) $\left.\mathrm{Cd}_{(\mathrm{mg} \mathrm{kg}}{ }^{-1}\right)$ & átlag & szórás & átlag & szórás & átlag & szign. \\
\hline Kontroll & 0,790 & $\pm 0,360$ & 0,690 & $\pm 0,270$ & 0,740 & $\mathrm{a}$ \\
\hline $\mathrm{Cd} 1$ & 15,030 & $\pm 3,570$ & 12,870 & $\pm 1,270$ & 13,950 & $a b$ \\
\hline $\mathrm{Cd} 2$ & 18,890 & $\pm 3,850$ & 20,570 & $\pm 3,790$ & 19,730 & $\mathrm{~b}$ \\
\hline $\mathrm{Cd} 3$ & 25,540 & $\pm 3,380$ & 23,890 & $\pm 4,504$ & 24,710 & $\mathrm{c}$ \\
\hline átlag/szign. & 15,060 & $\mathrm{~A}$ & 14,500 & A & & \\
\hline (10) $P\left(\mathrm{mg} \mathrm{kg}^{-1}\right)$ & átlag & szórás & átlag & szórás & átlag & szign. \\
\hline Kontroll & 1557 & \pm 321 & 1665 & \pm 323 & 1611 & $\mathrm{a}$ \\
\hline $\mathrm{Cd} 1$ & 1626 & \pm 138 & 1457 & \pm 153 & 1541 & $\mathrm{a}$ \\
\hline $\mathrm{Cd} 2$ & 1412 & \pm 138 & 1414 & \pm 182 & 1412 & $a b$ \\
\hline $\mathrm{Cd} 3$ & 1268 & \pm 198 & 1328 & \pm 164 & 1298 & $\mathrm{~b}$ \\
\hline átlag/szign. & 1466 & A & 1466 & A & & \\
\hline
\end{tabular}

PSII reakciócentrumok maximális kvantumhatékonysága (Fv/Fm); klorofilltartalom (CCI); Fv/Fm2 és CCI2 - 36 napos növény, gyökér elektromos kapacitása $\left(\mathrm{C}_{\mathrm{R}}\right) ; \mathrm{C}_{\mathrm{R}} 2$ 42 napos növény, membrán stabilitási index (MSI), kadmium- és foszforkoncentráció a hajtásban.

A statisztikai elemzés kéttényezős varianciaanalízissel készült, az eltérő betűk a szignifikáns különbséget jelölik $\mathrm{p}<0,05$. 
A gyökér/hajtás arány a kontrollhoz viszonyítva minden Cd-kezelésben nőtt. A nem mikorrhizált növényekre a Cd1-kezelésben 31,8\%-os, a Cd2-kezelésben 33,7 \%-os és a Cd3-kezelésben pedig 30,3\%-os gyökér/hajtás aránynövekedést figyeltünk meg (2. táblázat). Az AM gombával oltott növények a Cd1-kezelés hatására 23,1 \%-os, a Cd2-kezelés hatására 37,3 \%-os és a Cd3-kezelésre vonatkozóan 35,7 \%-os gyökér/hajtás arány növekedést mutattak. A $R$. intraradices gyökérkolonizációja $15 \%$-kal nagyobb gyökér/hajtás arányt eredményezett az AM gombával nem oltott növényekhez képest.

\section{2. táblázat}

Növekedési paraméterek alakulása kadmiumterhelés (kontroll: 0; Cd1: 1; Cd2: 2,5 és Cd3: 5 $\mathrm{mg} \mathrm{Cd} \mathrm{kg}{ }^{-1}$ nevelőközeg; $n=15$ ) hatására, mikorrhizált ( $\mathrm{AMF}+$ ) és nem mikorrhizált ( $\mathrm{AMF}-$ ) növényeken

\begin{tabular}{|c|c|c|c|c|c|}
\hline $\begin{array}{c}\text { (1) } \\
\text { Paraméterek/Kezelések }\end{array}$ & AMF- & $\mathbf{A N}$ & IF+ & & \\
\hline $\begin{array}{l}\text { (2) Gyökér száraz } \\
\text { tömeg (g/növény) }\end{array}$ & (3) átlag (4) szórás & átlag & szórás & átlag & (5) szign. \\
\hline Kontroll & $\pm 0,087$ & 0,363 & $\pm 0,076$ & 0,351 & $\mathrm{a}$ \\
\hline Cd1 & $\pm 0,104$ & 0,352 & $\pm 0,061$ & 0,337 & $\mathrm{a}$ \\
\hline $\mathrm{Cd} 2$ & $\pm 0,094$ & 0,327 & $\pm 0,091$ & 0,303 & $\mathrm{a}$ \\
\hline $\mathrm{Cd} 3$ & $\pm 0,062$ & 0,245 & $\pm 0,068$ & 0,230 & $\mathrm{~b}$ \\
\hline átlag/szign. & 0,288 & 0,322 & $\mathrm{~B}$ & & \\
\hline $\begin{array}{l}\text { (6) Hajtás száraz tömeg } \\
\text { (g/növény) }\end{array}$ & átlag szórás & átlag & szórás & átlag & szign. \\
\hline Kontroll & $\pm 0,268$ & 1,213 & $\pm 0,307$ & 1,242 & $\mathrm{a}$ \\
\hline Cd1 & $\pm 0,243$ & 0,953 & $\pm 0,125$ & 0,946 & b \\
\hline $\mathrm{Cd} 2$ & $\pm 0,195$ & 0,782 & $\pm 0,186$ & 0,787 & $\mathrm{~b}$ \\
\hline $\mathrm{Cd} 3$ & $\pm 0,140$ & 0,587 & $\pm 0,110$ & 0,599 & $\mathrm{c}$ \\
\hline átlag/szign. & 0,903 & 0,884 & $\mathrm{~A}$ & & \\
\hline $\begin{array}{c}\text { (7) Gyökér/Hajtás } \\
\text { arány }\end{array}$ & átlag szórás & átlag & szórás & átlag & szign. \\
\hline Kontroll & $\pm 0,046$ & 0,308 & $\pm 0,070$ & 0,288 & $\mathrm{a}$ \\
\hline $\mathrm{Cd} 1$ & $\pm 0,105$ & 0,376 & $\pm 0,086$ & 0,364 & b \\
\hline $\mathrm{Cd} 2$ & $\pm 0,109$ & 0,423 & $\pm 0,092$ & 0,390 & $\mathrm{~b}$ \\
\hline $\mathrm{Cd} 3$ & $\pm 0,047$ & 0,418 & $\pm 0,093$ & 0,383 & $\mathrm{~b}$ \\
\hline átlag/szign. & 0,331 & 0,381 & B & & \\
\hline $\begin{array}{l}\text { (8) Levélfelület } \\
\left(\mathrm{cm}^{2} / \text { növény) }\right.\end{array}$ & átlag szórás & átlag & szórás & átlag & szign. \\
\hline Kontroll & $98,790 \pm 24,860$ & 108,350 & $\pm 21,530$ & 103,570 & $\mathrm{a}$ \\
\hline Cd1 & $88,370 \pm 32,960$ & 91,990 & $\pm 24,990$ & 90,180 & $\mathrm{a}$ \\
\hline $\mathrm{Cd} 2$ & $56,510 \pm 20,980$ & 68,270 & $\pm 32,100$ & 62,390 & $\mathrm{~b}$ \\
\hline $\mathrm{Cd} 3$ & $37,800 \pm 13,310$ & 43,850 & $\pm 10,230$ & 40,825 & $\mathrm{c}$ \\
\hline átlag/szign. & $70,368 \quad \mathrm{~A}$ & 78,115 & $\mathrm{~A}$ & & \\
\hline
\end{tabular}

A statisztikai elemzés kéttényezős varianciaanalízissel készült, a betűk a szignifikáns különbségeket jelölik $\mathrm{p}<0,05$.

A Cd-kezelés a levélfelület csökkenését eredményezte, az AM gombával oltott és az oltatlan növényeken egyaránt. Az oltott növények nagyobb levélfelületủek 
voltak. Szignifikáns csökkenést a Cd2 növényre mértünk, ahol 39,8 \%-kal csökkent, illetve a Cd3 növényeken, ahol 60,6 \%-kal csökkent a levélfelület nagysága (2. táblázat).

Gyökérkolonizáció

Az R. intraradices gyökérkolonizációja csökkent a Cd-kezelésekben (2.ábra). $\mathrm{Az}$ AM gombával nem kezelt növények gyökerében AM gombaképleteket a mikroszkópos vizsgálat nem mutatott ki ( $\mathrm{M} \%=0$ és $\mathrm{A} \%=0)$.

A kontroll ( $\mathrm{Cd} 0)$ kezelés növényeihez képest a Cd1- és Cd2-kezelések a mikorrhizáltság intenzitásában (M\%) nem okoztak jelentős csökkenést. Szignifikáns különbséget a Cd3-kezelésekben találtunk, ahol a kontrollhoz képest 44 \%-kal kisebb intenzitást mértünk.

A növény-gomba szimbiotikus kapcsolat müködőképességére utaló arbuszkulum gazdagság (A\%) mértéke az M \%-hoz hasonlóan alakult. A kontrollhoz képest szignifikáns különbséget a $\mathrm{Cd} 3$ növények esetében találtunk, ahol az abszolút arbuszkuláltság 58,7 \%-kal csökkent.

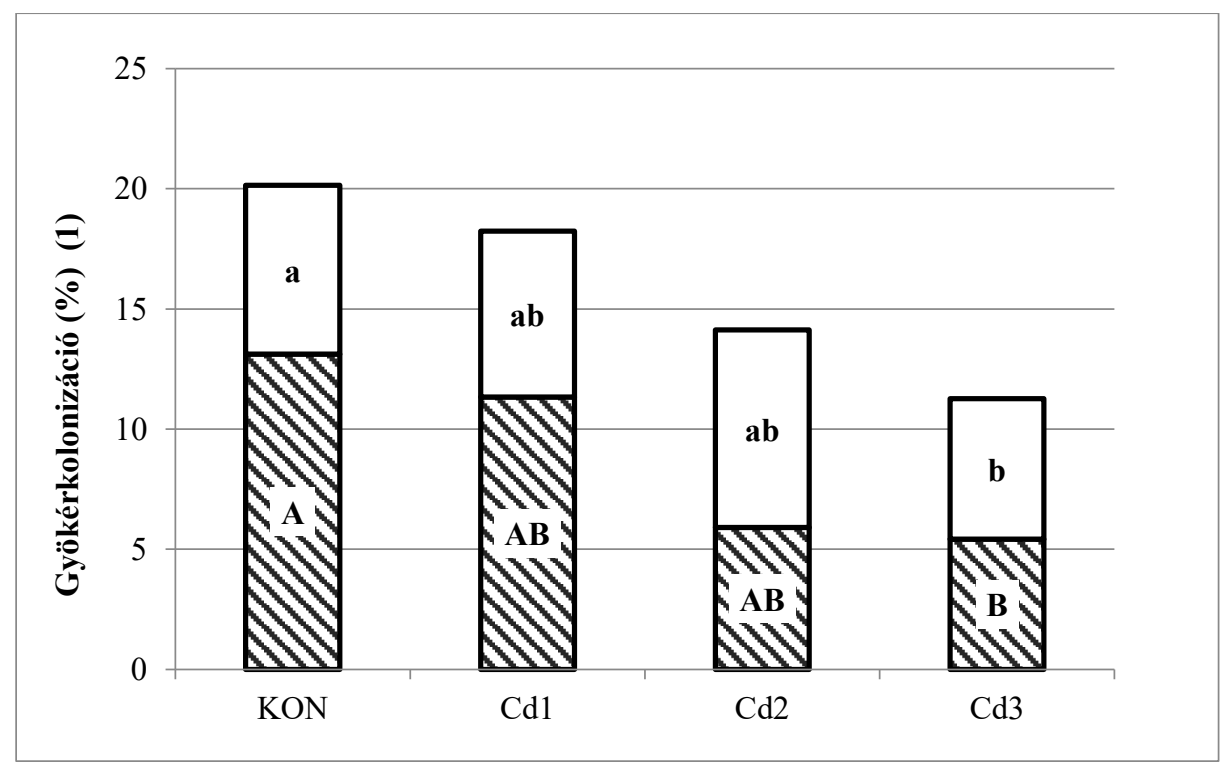

2. ábra

A Rhizoglomus intraradices gyökérkolonizációjának mértéke mikorrhizáltság intenzitás (M\%) és abszolút arbuszkuláltság ( $\mathrm{A} \%)$ mutatókkal ábrázolva.

M\% a teljes oszlopot, az A\% az azon belüli vonalkázott részt jelöli. A statisztikai elemzés egytényezős varianciaanalízissel készült, az eltérő betűk a szignifikáns különbséget jelölik $\mathrm{p}<0,05$. 


\section{Az eredmények értékelése}

A PCA alapján szétváltak a kadmiummal szennyezett és nem szennyezett variánsok a PC1 mentén. A kontroll növényeken mért paraméterek némileg átfedtek a Cd1-dózisban mértekkel, de egyértelműen elváltak a Cd2- és Cd3-dózisok értékeitől. Az AM gomba hatása is felismerhető a 1A. ábrán, de kevésbé markánsan, mint a szennyezettség hatása. A stresszélettani kutatásokban az adatmátrixok elemzéséhez hasznos módszer a PCA (FÜZY et al., 2019). Több kísérletben, PCA-val vizsgálták különböző - az élettani kutatásokban gyakorta alkalmazott-mérési módszerek indikációs érzékenységét. Só- és szárazságstressz hatásának kimutatására 20-20, növekedési, élettani, növény-AM gomba, illetve nitrifikáló baktérium szimbiotikus kapcsolatot, elemtartalmat jellemző paramétert elemeztek búza [Triticum aestivum L. cv. TC-33 és Mv. Hombár], szója [Glycine max L. cv. Alíz és Emese] és sziki öszirózsa [Tripolium pannonicum L.] növényeken. Megállapították, hogy a levelek klorofilltartalma és a PSII reakciócentrumok maximális kvantumhatékonysága jó indikátora a stressznek azonos növényállapotok (közel azonos biomassza és fejlettségi állapot) mellett. Továbbá a MSI és a $C_{R}$ érzékeny indikátora volt a só és szárazság okozta növényi stressznek. Vizsgálatunk során az MSI értékekre sem a Cd kezelések, sem pedig a mikorrhiza gombák gyökérbeli jelenléte nem volt jelentős hatással (1. táblázat).

Kísérletünkben a kadmiumra hatályos talajszennyezettség határértéket és annak többszörösét alkalmaztuk (szennyezettségi határérték (B) földtani közegre $=1 \mathrm{mg}$ kioldható (összes) $\mathrm{Cd} \mathrm{kg}^{-1}$ szárazanyag, a 6/2009. (IV. 14.) KvVM-EüM-FVM együttes rendelet alapján). A TC-33 búzafajta szakirodalmi adatok szerint érzékeny a Cd stresszel szemben (KovÁCs et al., 2014). WAHID és munkatársai (2009) vizsgálataihoz hasonlóan kísérletünkben a $\mathrm{Cd}$ fitotoxikus hatásaként a levelek sárgulását, zsugorodását és összepöndörödését figyeltük meg. A Cd-stressznek szignifikáns hatása volt a TC-33 búza klorofilltartalmára, maximális kvantumhatékonyságára, elektromos kapacitására, a hajtás- és gyökér biomasszára és a levélfelületre is (1. és 2. táblázat). Eredményeinkhez hasonlóan, SHAHABIVAND munkatársaival (2012) a fémszennyezés hatásaként csökkenő klorofilltartalmat és PSII reakciócentrumok maximális kvantumhatékonyságát mértek búzában. CI és munkatársai (2010) vizsgálataiban a búza PSII reakciócentrumok maximális kvantumhatékonysága és a levelek klorofill koncentrációja érzékeny indikátornak bizonyult a kadmium okozta stressz jelzésére. Eredményeinkhez hasonlóan ZHANG munkatársaival (2013) a Cd koncentráció növekedésének hatására a gyökér/hajtás arány növekedését detektálta pillangós növényeken. Számos kísérlet igazolta, hogy a levélfelület (LA) is jól jelzi a Cd jelenlétét, mivel az LA jelentősen csökken a Cd-terhelés hatására (EL-BELTAGI et al., 2010; LAI, 2015). RIZWAN és munkatársai (2016) megállapították, hogy a Cd-nak jelentős hatása van a gátolt gyökérnövekedésen és a felszívófelület csökkenésén keresztül a növények vízháztartására. Kísérletünkben a Cd negatív hatása a gyökerek biomasszájára és funkcionalitására jól nyomon követhetö volt a $C_{R}$ mérésekkel. CSERESNYÉS és munkatársai (2019) igazolták, hogy a só és szárazság okozta stressz hatása jól nyomon követhető a gyökérzet aktivitását detektáló $C_{R}$ mérésekkel. A különböző 
Cd-dózisok szignifikáns hatással voltak a $C_{R}$ értékekre. Méréseink szerint az AM gombával oltott növényeken a $C d$ hatására a $C_{R}$ érték enyhébb csökkenését tapasztaltuk. A mikorrhizált növények $\mathrm{C}_{\mathrm{R}}$-értékei nagyobbak voltak, mint a nem mikorrhizált növényeké. Ez egyrészt magyarázható az AM növénynövekedésre gyakorolt kedvező hatásával, ami szignifikánsan nagyobb gyökérbiomasszát eredményezett az AMF+ növényekben a nem oltottakhoz képest. Továbbá az AM gombák gyökérkolonizációja révén az extraradikális hifahálózatnak a gyökérzet tápanyagfelvevő felületét növelő hatásából is adódhat. CSERESNYÉS munkatársaival (2013) a gyökér-talaj együttes elektromos kapacitásának mérésére alapozva kimutatták a gyökéraktivitás növekedését Funneliformis mosseae és Rhizoglomus intraradices AM gombák keverékével oltott kukoricán, miközben a gyökerek biomasszája és felülete az oltás hatására nem változott. TAKÁCS és munkatársai (2014) $C_{R}$ méréssel két $A M$ gombafaj között gyökérkolonizáció vizsgálatával funkcionális különbséget állapítottak meg.

SHAHABIVAND és munkatársai (2012) eredményeihez hasonlóan esetünkben a $R$. intraradices oltás kedvező hatással volt a növények gyökerének növekedésre, ezáltal a gyökér /hajtás arány változására. A Cd felhalmozása a gyökerekben nagyobb mértékủ volt, mint a hajtásban (AMF+: 79,7 $\mathrm{mg} \mathrm{kg}^{-1}$ és AMF-: 63,3 mg kg${ }^{-1}$ ) (LuX et al., 2011; TAKÁCS \& VÖRÖS, 2003), amelynek mértékét az AMF oltás az alacsony kolonizációs értékek ( $\mathrm{M} \%$ és $\mathrm{A} \%$ ) mellett is mérsékelte (1. táblázat, 2. ábra). Ez az eltérés az AM gombák fémvisszatartó hatásán túl a biomassza növekedéséből adódó hígulásra is visszavezethető (GÖHRE \& PASZKOWSKI, 2006). Az AM gombák egyik legjelentősebb hatása, a növények P-felvételének fokozása, azonban a mikorrhizált és nem mikorrhizált növények foszforkoncentrációja között nem volt szignifikáns eltérés (1. táblázat). A pázsitfúfélék mikorrhizafüggése kicsi (TAWARAYA, 2003), azonban a búza fajtától és az AM gombafajtól függően - a gyökerek kolonizációjában - jelentös különbségek lehetnek (RYAN et al., 2005; CSERESNYÉS et al., 2018).

Vizsgálataink során a TC-33 búzafajtán a Cd már kis koncentrációban is jelentösen gátolta a növények növekedését és fejlödését. A Cd okozta stressz jelzésére érzékeny paraméternek bizonyultak a klasszikus növényélettani mutatók és a $C_{R}$, továbbá a hajtás-, a gyökér biomassza és a levélfelület. Kísérletünkben a legérzékenyebb stressz-indikátornak a $C_{R}$ és a növekedési paraméterek bizonyultak. A $C_{R}$ nemcsak a kadmium okozta stressz, hanem az AM gomba oltás kedvező hatásnak kimutatására is hatékony módszer.

\section{Összefoglalás}

Klímakamrás tenyészedény-kísérletben vizsgáltuk a talajban levő kadmium (Cd) stressz és az arbuszkuláris mikorrhiza gomba (AMF) oltás a hatását búzán [Triticum aestivum L. cv. TC-33]. Választ kerestünk arra, hogy a nevelöközeg különbözö mértékủ Cd-szennyezése $\left(0 ; 1 ; 2,5\right.$ és $5 \mathrm{mg} \mathrm{Cd} \mathrm{kg}^{-1}$ riolit-vermikulit nevelőközeg) milyen növényi stresszválasz alapján állapítható meg. A Cd-stressz hatásának detektálására in situ és destruktív módszerek alapján mért klasszikus növényélettani és növekedési indikátorokat használtunk. Módszertani szempontból 
vizsgáltuk az elektromos kapacitásmérés $\left(\mathrm{C}_{\mathrm{R}}\right)$ alkalmasságát a $\mathrm{Cd}$ által kiváltott, a gyökérrendszer aktivitását mutató változásokat.

A tenyészidőszakban in situ monitoroztuk a PSII reakciócentrumok maximális kvantumhatékonyságát $(\mathrm{Fv} / \mathrm{Fm})$, a klorofilltartalmat $(\mathrm{CCI})$, a gyökér-talaj együttesben mérhető $C_{R}$-t. A kísérlet bontása után meghatároztuk a sejtmembrán stabilitási indexet (MSI), a növények kadmium- és foszforkoncentrációit, a gyökér(RDM) és a hajtástömeget (SDM), valamint a levelek felületét (LA). Az AM gombák gyökérkolonizációját mikroszkópos vizsgálattal becsültük. A kapott adatmátrix statisztikai elemzéséhez főkomponens-analízist (PCA) használtunk, ami megfelelö módszernek bizonyult az in situ és a destruktív mérési módszerek érzékenységbeli különbségének, indikációs erejének összehasonlító vizsgálatára.

A PCA szerint az összes paramétert figyelembe véve a szennyezett és nem szennyezett variánsok között elválást tapasztaltunk a PC1 fökomponens mentén. A Cd1-dózis néhol átfedést mutatott a kontroll növényeken mért paraméterekkel, a Cd2- és a Cd3-dózisok mért értékeitöl viszont egyértelmủen elváltak. A paraméterek jól tükrözik, hogy az AM gomba oltás enyhítette a kadmium által okozott stressz hatást. A fökomponens analízissel az AM hatás is kimutatható, de a szétválás a mikorrhizált és nem mikorrhizált növények között kevésbé kifejezett, mint a Cd-szennyezésé. A Cd-stressz szignifikánsan csökkentette a levelek Fv/Fm értékét, klorofilltartalmát, a $C_{R}$-értéket, a hajtás- és a gyökérbiomasszát, illetve a levélfelületet. $A C_{R}$ és a növekedési paraméterek azok az indikátorok, amelyek a TC-33 búzafajtán legjobban jellemezték a kadmium mérgező hatását.

Kulcsszavak: arbuszkuláris mikorrhiza gomba (AMF), búza (Triticum aestivum L.), fökomponens analízis (PCA), gyökér elektromos kapacitás $\left(\mathrm{C}_{\mathrm{R}}\right)$, kadmiumstressz, stresszindikáció

\section{Köszönetnyilvánítás}

A 115714 sz. projekt a Nemzeti Kutatási, Fejlesztési és Innovációs Alapból biztosított támogatással, a K-16 pályázati program finanszírozásában valósult meg. A tanulmány elkészítését a Magyar Tudományos Akadémia Bolyai János Kutatási Ösztöndíja támogatta.

\section{Irodalom}

ANJUM, N. A., UMAR, S., \& IQBAL, M., 2014. Assessment of cadmium accumulation, toxicity, and tolerance in Brassicaceae and Fabaceae plants-implications for phytoremediation. Environmental Science and Pollution Research. 21. 10286-10293.

BRUNDRETT, M. C., \& TEDERSOO, L., 2018. Evolutionary history of mycorrhizal symbioses and global host plant diversity. New Phytologist. 220. 1108-1115.

Chaves, M. M., FleXAS, J., \& PINHEIRO, C., 2009. Photosynthesis under drought and salt stress: regulation mechanisms from whole plant to cell. Annals of Botany. 103. $551-560$. 
Ci, D., Jiang, D., Wollenweber, B., DAI, T., Jing, Q., \& CAO, W. (2010). Cadmium stress in wheat seedlings: growth, cadmium accumulation and photosynthesis. Acta Physiologiae Plantarum, 32. (2) 365-373.

CsATHÓ, P., 1994. A környezet nehézfém szennyezettsége és az agrártermelés. Magyar Tudományos Akadémia Talajtani és Agrokémiai Kutató Intézete. Budapest. Hungary. 172.

CSERESNYÉS, I., TAKÁCS, T., VÉGH, R. K., ANTON, A. \& RAJKAI, K., 2013. Electrical impedance and capacitance method: a new approach for detection of functional aspects of arbuscular mycorrhizal colonization in maize. European Journal of Soil Biology. 54. 25-31.

CSERESNyÉS, I., TAKÁCS, T., KovÁCS, R., FÜZY, A., \& RAJKAI, K., 2018. Szárazságstressz és mikorrhiza gombák búza gyökérnövekedésére gyakorolt hatásának monitorozása elektromos kapacitás mérésével. Agrokémia és Talajtan. 67. 213-225.

Cseresnyés, I., TAKÁcs, T., Sepovics, B., KovÁcs, R., FÜZY, A., PARÁdi, I., \& RAJKAI, K., 2019. Electrical characterization of the root system: a noninvasive approach to study plant stress responses. Acta Physiologiae Plantarum. 41. 169.

El-Beltagi, H. S., Mohamed, A. A., \& Rashed, M. M., 2010. Response of antioxidative enzymes to cadmium stress in leaves and roots of radish (Raphanus sativus L.). Notulae Scientia Biologicae. 2. 76-82.

Ferrol, N., GonzÁlez-Guerrero, M., Valderas, A., Benabdellah, K., \& AZCÓN-AGUILAR, C., 2009. Survival strategies of arbuscular mycorrhizal fungi in Cu-polluted environments. Phytochemistry Reviews. 8. 551.

FÜZY, A., TÓTH, T., \& BIRÓ, B., 2007. Mycorrhizal colonisation can be altered by the direct and indirect effect of drought and salt in a split root experiment. Cereal Research Communications. 35. 401-404.

FÜZY, A., KovÁcs, R., CSERESNYÉS, I., PARÁDI, I., SZILI-KovÁCS, T., KELEMEN, B., RAJKAI, K., \& TAKÁCS, T., 2019. Selection of plant physiological parameters to detect stress effects in pot experiments using principal component analysis. Acta Physiologiae Plantarum. 41. 56.

GÖHRE, V., \& PASZKOWSKI, U., 2006. Contribution of the arbuscular mycorrhizal symbiosis to heavy metal phytoremediation. Planta. 223. 1115-1122.

JHA, C. K., \& SARAF, M., 2015. Plant growth promoting rhizobacteria (PGPR): a review. Journal of Agricultural Research and Development. 5. 108-119.

HuAng, M., ZhOU, S., Sun, B., \& ZHAO, Q., 2008. Heavy metals in wheat grain: assessment of potential health risk for inhabitants in Kunshan. China. Science of the Total Environment. 405. 54-61.

KHAN, M. A., KHAN, S., KHAN, A., \& Alam, M., 2017. Soil contamination with cadmium, consequences and remediation using organic amendments. Science of the Total Environment. 601. 1591-1605.

KovÁcs, V., GONDOR, O. K., SZAlai, G., DARKÓ, É., MAJlÁth, I., JANDA, T., \& PÁL, M., 2014. Synthesis and role of salicylic acid in wheat varieties with different levels of cadmium tolerance. Journal of Hazardous Materials. 280. 12-19. 
Krishnamoorthy, R., Venkatramanan, V., Senthilkumar, M., Anandham, R., Kumutha, K., \& SA, T., 2019. Management of Heavy Metal Polluted Soils: Perspective of Arbuscular Mycorrhizal Fungi. In: SHAH, S., VENKATRAMANAN, V., PrasaD, R. (eds.): Sustainable Green Technologies for Environmental Management. Springer. Singapore. 67-85.

LAI, H. Y., 2015. Effects of leaf area and transpiration rate on accumulation and compartmentalization of cadmium in Impatiens walleriana. Water, Air \& Soil Pollution. 226. 2246.

LuX, A., MartinkA, M., VACUlíK, M., \& White, P. J. 2011. Root responses to cadmium in the rhizosphere: a review. Journal of Experimental Botany. 62. 21-37.

LI, L., ZHANG, Q., \& HUANG, D., 2014. A review of imaging techniques for plant phenotyping. Sensors. 14. 20078-20111.

MSZ 21470-50:2006: Környezetvédelmi talajvizsgálatok. Az összes és az oldható toxikus elem-, a nehézfém- és a króm (VI) tartalom meghatározása.

PARMAR, P., KUMARI, N., \& SHARMA, V. 2013. Structural and functional alterations in photosynthetic apparatus of plants under cadmium stress. Botanical Studies. 54. 45.

PARNISKE, M., 2008. Arbuscular mycorrhiza: the mother of plant root endosymbioses. Nature Reviews Microbiology. 6. 763-775.

PHILLIPS, J. M. \& HAYMAN, D.S., 1970. Improved procedures for clearing roots and staining parasitic and vesicular-arbuscular mycorrhizal fungi for rapid assessment of infection. Transactions of the British Mycological Society. 55. 157-160.

R CORE TEAM, 2019.: A language and environment for statistical computing. R Foundation for Statistical Computing, Vienna, Austria. URL https://www.R-project.org/.

Rizwan, M., Ali, S., AdreES, M., Rizvi, H., ZiA-UR-ReHMAn, M., HANnAN, F., \& OK, Y. S., 2016. Cadmium stress in rice: toxic effects, tolerance mechanisms, and management: a critical review. Environmental Science and Pollution Research. 23. 17859-17879

Ryan, M. H., VAn HerwaArden, A. F., Angus, J. F., \& KirkegaArd, J. A., 2005. Reduced growth of autumn-sown wheat in a low-P soil is associated with high colonisation by arbuscular mycorrhizal fungi. Plant and Soil. 270. 275-286.

SAIRAM, R. K., DESHMUKH, P.S., \& SHUKLA, D.S., 1997. Tolerance of drought and temperature stress in relation to increased antioxidant enzyme activity in wheat. Journal of Agronomy and Crop Science. 178. 171-178.

Shahabivand, S., Maivan, H. Z., Goltapeh, E. M., Sharifi, M., \& Aliloo, A. A., 2012. The effects of root endophyte and arbuscular mycorrhizal fungi on growth and cadmium accumulation in wheat under cadmium toxicity. Plant Physiology and Biochemistry. 60. 53-58.

Shanying, H. E., Xiaoe, Y. A. N. G., Zhenli, H. E., \& Baligar, V. C. 2017. Morphological and physiological responses of plants to cadmium toxicity: a review. Pedosphere. 27. 421-438. 
SIMON, L. 2014. Potentially harmful elements in agricultural soils. In: BINI, C. \& BECH, J. (eds.), PHEs, Environment and Human Health. Potentially Harmful Elements in the Environment and the Impact on Human Health. Springer, Dordrecht, Heidelberg, New York, London pp. 85-137., 142-150.

SMith, S. E., \& SMith, F. A., 2012. Fresh perspectives on the roles of arbuscular mycorrhizal fungi in plant nutrition and growth. Mycologia. 104. 1-13.

SZABÓ, A., PoKOVAI, K., RAGÁlyi, P., RÉKÁSI, M., SÁNDOR, R., BERnHARDT, B., \& CSATHÓ, P., 2019. Nehézfém-és egyéb toxikus mikroelem-terhelés tartamhatása a talajból mért visszanyerési százalékuk alakulására szabadföldi kísérletekben. Agrokémia és Talajtan. 68. 293-314.

TAKÁCS, T., \& VÖRÖS, I., 2003. Effect of metal non-adapted arbuscular mycorrhizal fungi on $\mathrm{Cd}, \mathrm{Ni}$ and $\mathrm{Zn}$ uptake by ryegrass. Acta Agronomica Hungarica. 51. 347-354.

TAKÁCS, T., 2012. Site-specific optimization of arbuscular mycorrhizal fungi mediated phytoremediation. In: ZAIDI, A., WANI, P. A., KHAN, M. S. (eds.): Toxicity of heavy metals to legumes and bioremediation. Springer. Vienna. 179-202.

TAKÁCS, T., FÜZY, A., RAJKAI, K., \& CSERESNYÉS, I., 2014. Investigation of arbuscular mycorrhizal status and functionality by electrical impedance and capacitance measurement. Acta Biologica Szegediensis. 58. 55-59.

TAWARAYA, K., 2003. Arbuscular mycorrhizal dependency of different plant species and cultivars. Soil Science and Plant Nutrition. 49. 655-668.

Trouvelot, A., Kough, J.L., \& GianinaZZi-Pearson, V., 1986. Mesure du taux de mycorhization VA d'un système radiculaire. Recherches et methods d'estimation ayant une signification fonctionnelle. In: GIANINAZZI-PEARSON, V., GiAnINAZZI, S. (eds.): Physiological and genetical aspects of mycorrhizae. INRA. Paris. 217-221.

Verslues, P. E., Agarwal, M., Katiyar-Agarwal, S., Zhu, J., \& Zhu, J. K., 2006. Methods and concepts in quantifying resistance to drought, salt and freezing, abiotic stresses that affect plant water status. The Plant Journal. 45. 523-539.

WAHID, A., ARSHAD, M., \& FAROOQ, M., 2009. Cadmium phytotoxicity: responses, mechanisms and mitigation strategies: a review. In: LICHTFOUSE, E., (ed.): Organic Farming, Pest Control and Remediation of Soil P. 371-403. Springer. Dordrecht.

Wobbrock, J. O., Findlater, L., Gergle, D., \& Higgins, J. J., 2011. The aligned rank transform for nonparametric factorial analyses using only anova procedures. In Konstan, J. A. , CHI, E., HÖÖK, K.(eds.): Proceedings of the SIGCHI conference on human factors in computing systems. ACM Press. New York. 143-146.

Zhang, Z., LiU, C., WANG, X., \& SHI, G., 2013. Cadmium-induced alterations in morpho-physiology of two peanut cultivars differing in cadmium accumulation. Acta Physiologiae Plantarum. 35. 2105-2112. 
6/2009. (IV. 14.) KVVM-EÜM-FVM EGYÜTTES RENDELET a földtani közeg és a felszín alatti víz szennyezéssel szembeni védelméhez szükséges határértékekről és a szennyezések méréséről.

\title{
Comparative study of in situ and destructive measurements for indication of cadmium stress on wheat
}

\author{
$1 *$ B. Kelemen, ${ }^{1}$ A. FÜZy, ${ }^{1}$ I. Cseresnyés, ${ }^{1,2}$ I. PARÁdi, ${ }^{1}$ R. KovÁcs, ${ }^{1}$ K. RAJKAI, \\ ${ }^{1} \mathrm{~T}$. TAKÁCS \\ ${ }^{1}$ Institute for Soil Sciences and Agricultural Chemistry, Centre for Agricultural \\ Research, Budapest (Hungary) \\ ${ }^{2}$ Eötvös Lóránd University Faculty of Science, Department of Plant Physiology and \\ Molecular Plant Biology, Budapest (Hungary)
}

\begin{abstract}
Summary
The effects of cadmium (Cd) stress and arbuscular mycorrhizal fungus (AMF) inoculation were investigated in wheat [Triticum aestivum L. cv. TC-33] under controlled conditions. The experiments aimed to reveal what stress responses belong to the different levels of $\mathrm{Cd}$ load in the growth medium $\left(0 ; 1 ; 2,5\right.$ and $5 \mathrm{mg} \mathrm{Cd} \mathrm{kg^{-1 }}$ substrate). To detect the effect of Cd stress, we compared plant physiological and growth indicators measured with both in situ and destructive methods. Electrical capacitance $\left(C_{R}\right)$ was evaluated during the experiments as a method to indicate stress responses through of $\mathrm{Cd}$-induced root system changes.

During the growth period, the photosynthetic activity ( $\mathrm{Fv} / \mathrm{Fm})$, the chlorophyll content index (CCI) of the leaves, and the $\mathrm{C}_{\mathrm{R}}$ of the root-soil system were monitored in situ. After harvest, the membrane stability index (MSI), the cadmium and phosphorus concentrations of the plants, the root dry mass (RDM), the shoot dry mass (SDM) and the leaf area (LA) were measured. The root colonization of AM fungi was estimated by microscopic examination. Data matrices were evaluated with principal component analysis (PCA) which had been proved to be a good statistical method to the sensitivity between measurement methods.

Taking all parameters into account in the PCA, a complete separation was found between the contaminated and non-contaminated variants along the main component $\mathrm{PC} 1$. The measured values of the $\mathrm{Cd} 1$ treatment sometimes overlapped with that of control plants, but differed from that of the $\mathrm{Cd} 2$ and $\mathrm{Cd} 3$ doses. The parameters well reflected that AMF inoculation alleviated the stress caused by Cd. PCA shows a visible effect of AM, but the separation between mycorrhizal and non-mycorrhizal plants is weaker than that between $\mathrm{Cd}$ contaminated and non-treated ones. The $\mathrm{Cd}$ stress significantly decreased the Fv/Fm, CCI, $\mathrm{C}_{R}, \mathrm{SDM}, \mathrm{RDM}$ and LA. The $\mathrm{C}_{\mathrm{R}}$ and growth parameters proved to be the best indicators to characterize the $\mathrm{Cd}$ phytotoxicity in the TC-33 wheat cultivar.
\end{abstract}


Keywords: arbuscular mycorrhizal fungi (AMF), cadmium stress, principal component analysis $(\mathrm{PCA})$, root electrical capacitance $\left(\mathrm{C}_{\mathrm{R}}\right)$, stress indication, wheat (Triticum aestivum $\mathrm{L}$.)

\section{Tables and figures}

Table 1. Effect of cadmium treatments (control: 0; Cadmium 1: 1; Cadmium 2: 2.5 and Cadmium 3: $5 \mathrm{mg} \mathrm{Cd} / \mathrm{kg}$ substrate) on plant stress response and element uptake in mycorrhizal (AMF+) and non-mycorrhizal (AMF-) plants (1) Parameters/Treatments (2) photosynthetic activity (Fv/Fm); Fv/Fm2- 36-dayold plant, (3) average (4) standard deviation (5) significance (6) chlorophyll content (CCI); CCI2- 36-day plant, (7) root electrical capacity (CR); CR2- 42day-old plant, (8) membrane stability index (MSI), (9) Cadmium concentration in the shoot $\left(\mathrm{mg} \mathrm{kg}^{-1}\right),(10)$ Phosphorus concentration in the shoot $\left(\mathrm{mg} \mathrm{kg}^{-1}\right)$. Statistics were performed by two-way ANOVA $(\mathrm{p}<0,05)$.

Table 2. Effect of cadmium treatments (control: 0; Cadmium 1: 1; Cadmium 2: 2.5

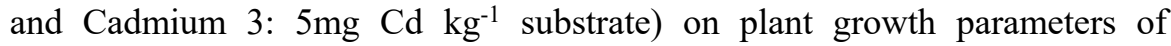
mycorrhizal (AMF+) and non-mycorrhizal (AMF-) plants. (1) Parameters/Treatments, (2) Root dry mass (g/plant), (3) average, (4) standard deviation, (5) significance, (6) Shoot dry mass (g/plant), (7) Root/shoot ratio, (8) Leaf area $\left(\mathrm{cm}^{2} /\right.$ plant). Statistics were performed by two-way ANOVA $(\mathrm{p}<0,05)$.

Figure 1. The result of principal component analysis (PCA). (A) Distribution of samples in the co-ordinate system, (B) separation of parameters. Markings: photosynthetic activity (Fv/Fm); Fv/Fm1- 22-day-old plant and Fv/Fm236-day-old plant, chlorophyll content (CCI); CCI1- 22-day plant and CCI2- 36day plant, root electrical capacity $\left(\mathrm{C}_{\mathrm{R}}\right)$; CR1-26-day-old plant and CR2 42-dayold plant, dissipation factor (D); D1 - 26-day-old plant and D2- 42-day-old plant, membrane stability index (MSI); root dry mass (RDM); shoot dry weight (SDM); root/shoot ratio (RSR); leaf area (LA).

Figure 2. Rate of the root colonization of Rhizoglomus intraradices. Fungal colonization intensity $(\mathrm{M} \%)$ and arbuscule richness of roots $(\mathrm{A} \%)$ represent with index. (1) Colonization of roots (\%). M\% represents the entire column and $\mathrm{A} \%$ represents the crosshatched part. Statistics were performed by one-way ANOVA $(\mathrm{p}<0,05)$.

Open Access nyilatkozat: A cikk a Creative Commons Attribution 4.0 International License (https://creativecommons.org/licenses/by/4.0) feltételei szerint publikált Open Access közlemény, melynek szellemében a cikk bármilyen médiumban szabadon felhasználható, megosztható és újraközölhetö, feltéve, hogy az eredeti szerzö és a közlés helye, illetve a CC License linkje és az esetlegesen végrehajtott módosítások feltüntetésre kerülnek. (SID_1) 